Notes 
Lyubov Kostogryzova

Ekaterinburg

\section{SOME NOTES \\ ABOUT THE RELIGIOUS POLICY \\ OF JUSTINIAN THE GREAT}

The greatness of Justinian I (527-565) and his activity has traditionally attracted the attention of researchers. Nobody can say that his religious policy has not been studied. All scholars believe that the concept of the symphony of Church and State powers was the great achievement of this Emperor, but as a rule they say nothing about the reasons for the appearance of this concept. Let's try to discover these reasons and to see regularity in Justinian's religious policy, in which all issues were connected.

It is a known fact that the restoration of the Great Roman Empire in the first-second centuries, was the guiding principle of Justinian's policy. So the emperor wrote in 534: "hoc etiam deprecantes exoramus precibus sanctae et gloriosae semper virginis et dei genetricis mariae, ut, quidquid minus est rei publicae nostrae, per nos, ultimos servos suos, restituat in suo nomine deus et dignos nos faciat servitium eius adimplere" (CJ.I.27.1.9). ${ }^{1}$

Political unity demands the ideological unity, that is the unity of faith or religion. This unity was understood as the unity of worship and devotion which took place in the pagan tradition. And if some branch of Christianity deviated from this unity, this branch was considered heretical. Justinian also thought so at the beginning of his ruling that's why he promulgated some antiheretical laws (C.J.1.5, 10). Yet later he realized that all Christians including heretics were Christians, that is, they had the essential unity of faith. Thus the Emperor began to fight against pagans, Jews and other non-Christian religions. So in 529 the teaching Academy of Plato of Athens was placed under state control by order of Justinian; paganism was greatly suppressed (CJ.1.10-11). According to Justinian laws, Orthodox children could not be disinherited by their Jewish parents (CJ.1.5.13.), no Jew was allowed to possess and to own Christian slaves, or slaves desiring to

(1) Codex Justinianus (Berlin, 1880) (Corpus Juris Civilis 2) (hereafter CJ). 
become Christian (CJ.1.3.54; CJ.1.10.2). Complete destruction of Samaritan synagogues was ordered (CJ.1.5.17); synagogues were to be turned into churches (nov. 37); Jews might not build new synagogues and they were not allowed to lease Orthodox property (nov. 131).

At the same time Justinian understood that dissension within the Christian Church undermined the unity of the Church and thereby the unity of the Empire. The Emperor embodied this unity of the Empire. And Justinian wanted the figure of the emperor to be beyond the religious fight. That's why he displaced the emperor from participation in this fight. And that's why he divided some authorities between

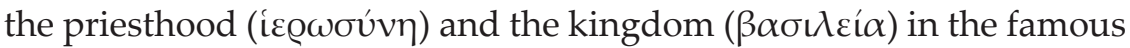
preface for his 6th Novella (New Constitution):

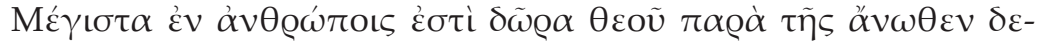

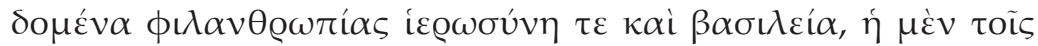

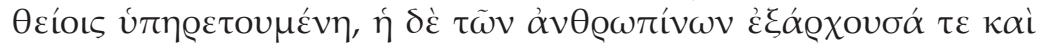

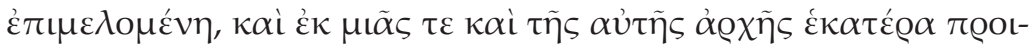

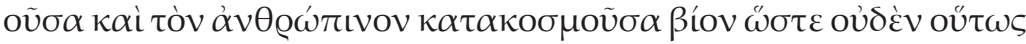

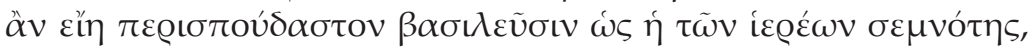

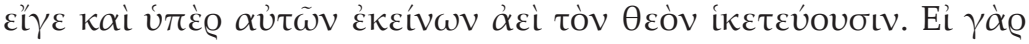

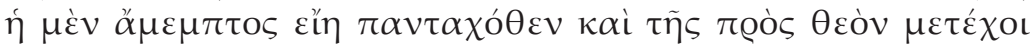

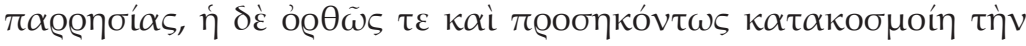

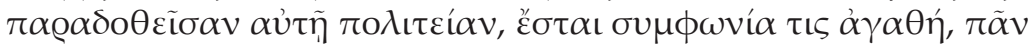

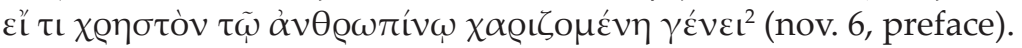

Thus, the priesthood embodies the spiritual sphere and the kingdom embodies the material sphere. Both of them arise from one source, both of them are gifts of God so they are equal. It seems that Justinian emphasized this equality. The kingdom takes care of human matters and the emperor has to think about the affairs of state, especially about keeping peace in the united Empire. Meanwhile the priesthood has to serve God's matters and to keep peace in the Church. Then Justinian talks about consent ( $\sigma v \mu \phi \omega v i \alpha)$ between both the kingdom and the priesthood.

It seems to me that Justinian's brilliant idea is contained in this well-known fragment. Firstly the figure of emperor was exonerated from fault for Church dissension and secondly the figure of Emperor was relieved from the position of pontifex maximus. Although Gratian

(2) R. Scholl and W. Kroll (eds.), Flavius JUSTINIANUS Imperator. Novellae (Berlin: Weidmann, 1895, repr. 1968) (Corpus iuris civilis 3) 1-795. 
resigned from this title in 382, it was done only formally and the policy of the next emperors shows that they tried to control the religious life of their subjects. Now all duties of the great pontific were passed to the Church. But it was not a complete deviation of the Emperor from religious matters. He continued to take part in these matters because the majority of his subjects were Christians and Christianity really became the ideological basis of the Byzantine empire. Justinian's New Constitutions are real evidence of his participation in the religious life. But this intervention received definite limits and if these limits were broken it would be a reason for conflicts between the Emperor and clergy. If the Emperor formerly symbolized the religious unity as pontifex maximus, henceforth he began to symbolize only political unity as a supreme ruler unlike rex or princeps. And religious dissension couldn't undermine both the unity of the Empire and the perception of this unity.

When Justinian underlined one source for the kingdom and the priesthood ( $\dot{\kappa} \kappa \mu \mathrm{i} \tilde{\varsigma} \tau \varepsilon \kappa \alpha i \mathrm{i} \tilde{\eta} \varsigma \alpha \dot{v} \tau \tilde{\eta} \varsigma \dot{\alpha} \varrho \chi \tilde{\eta} \varsigma)$ he spoke about the equal role of each of them in keeping the Empire's unity because the emperor cares for political unity and the Church cares for religious unity. It means that Justinian refused of his own free will to be responsible for the spiritual sphere of life of his subjects in favour of the Church. In other words the Emperor determined his duties personally thereby rejecting caesarepapism. Also Justinian did not give the Church representational powers, that is, the powers to personify the unity of the empire. So he emphasized the impossibility of papocaesarism, that is, subjecting the state to the Church. And when he spoke about symphony he had in mind only the unity of the State and Church.

But the majority of researchers consider that it was Justinian who tried to subject the Church to the State. So S. Runcimen considered that Justinian's rule was the time of the highest power of the Emperor over the Church. ${ }^{3}$ V. Asmus insists that Justinian had formulated the concept of the symphony of the kingdom and the priesthood in reply to doctrines of the Roman Popes of the fifth and the sixth centuries concerning the superiority of the priesthood. The researcher had seen in the 6th Novella that the emperor "takes care of true dogma, of the honour of priests, of observance of canons, in other words of the

(3) С. РАнсимен, Восточная схизма. Византийская теократия (Москва, 1998) 165. 
Church establishment." ${ }^{4}$ According to A. Kartashev, Justinian was a bishop of Church domestic affairs. ${ }^{5}$

All accusations against Justinian are based on the position that there are detail regulations of ecclesiastical property, election and rights of bishops, priests and abbots, monastic life, residential obligations of the clergy, conduct of the divine service, episcopal jurisdiction in the Codex and Novellae. I agree with D. Simon that Justinian believed that through law it was possible to subject all conflict resolution in his society to a written set of rules. ${ }^{6}$ Therefore all problems of the Church, which was part of society, would be solved with the help of laws. And the Emperor equated Church canons with laws, causing historians to accuse him of attempting to submit the Church to the State. He said that the sacred canons have the same power as public laws in the state... and crimes against canons are not endurable in a state according to the laws of the state. In 545 Justinian wrote which canons had to be public laws.

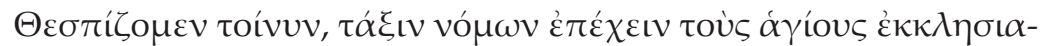

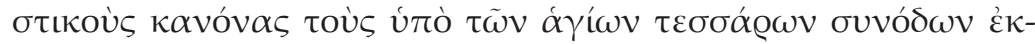

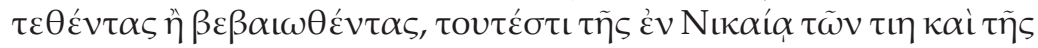

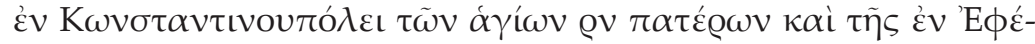

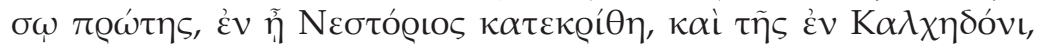

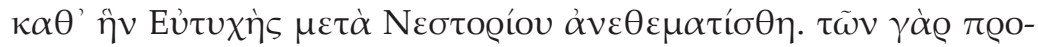

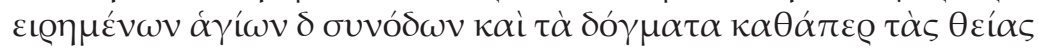

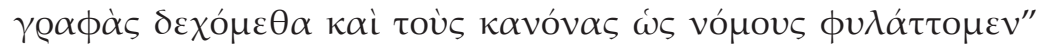
(nov. 131, cap. 1).

So when Justinian said that he cared for the sacred canons as public laws, firstly he grounded his intervention in Church matters and secondly he equalized the kingdom and priesthood, again confirming the consent between them.

In other words Justinian tried to follow his model of symphony in his legacy. And due to him caesaropapism in Byzantium de jure be-

(4) В. Асмус, Церковные полномочия византийских императоров, in: Православная государственность: 12 писем об империи (Санкт-Петербург, 2003) 35.

(5) А. В. КАРТАшев, Вселенские соборы (Клин, 2002) 458.

(6) D. Simon, Legislation as both a World Order and a Legal Order, in: A. LAiou and D. Simon (eds.), Law and Society in Byzantium: Ninth-Twelfth Centuries (Washington, D.C.: Dumbarton Oaks Research Library and Collection, 1994) 9. 
came impossible. But de facto powerful emperors always tended to control all matters including ecclesiastical life, weak emperors were to be controlled by Constantinople patriarchs and wise emperors tended to follow the model of the symphony.

As for Justinian himself we can see that he was so mighty a figure that it was very hard for him not to weaken his powers which were determined by himself. But all his prescriptions relating to dogmatic problems as a rule were discussed by bishops. And it's difficult to agree with A. Velichko with his interpretation of the 6th Novella (New Constitution), who believes that Justinian did not set off the kingdom against the priesthood because the Emperor considered that all humanity was the Church and the Emperor himself had to care both for the Churches and the nation. ${ }^{7}$ I think that Justinian wanted to express only the words that he had written, but different constructions of his concept of the symphony of Church and State powers mean that this problem is quite urgent nowadays.

(7) А. М. Величко, Церковь и император в византийской и русской истории (Санкт-Петербург, 2006) 56-57. 